\title{
CONTRACTS WITHOUT CONSIDERATION; THE SEAL AND THE UNIFORM WRITTEN OBLIGATIONS ACT
}

The private seal, introduced into England by the Normans, ${ }^{\mathrm{x}}$ began early to play an important rôle in the law of contracts. At first, only the great nobles had distinctive seals, ${ }^{2}$ but by the reign of Edward I, they were in use by all freemen and upper class villeins, as a result, no doubt, of their indispensability in the making of deeds and contracts. At a time when the ability to read and write was rare and the binding effect of a signature not yet conceived, the seals were the only medium of attesting the validity of contracts and of identifying their makers. The renaissance, however, was accompanied by widespread literacy and a great increase in commerce. The need for a commercial device less unwieldy than the sealed contract probably contributed to the development of the action of assumpsit, thereby providing a means for the enforcement of simple contracts in the King's courts; the increase in literacy deprived the seal of its original raison d'etre, so that the seal's chief function was no longer its ability to identify the maker, but rather to represent the maker's intention in such a way as to subject him to the special rules ${ }^{3}$ which governed sealed instruments, and which rendered them immune from the attacks to which simple contracts were subject. 4

There have been two great trends away from this common law position. The first of these is the gradual diminution of the powers of the seal,, 5 till today it is really significant only insofar as it satisfies, or obviates, the requirements of consideration. The second is the liberalization of the requirements for the seal as a formality. The seal when first used involved an impression upon wax. ${ }^{6}$ Then wafers were permitted instead of wax; $;^{7}$ and then an impression on the paper itself was regarded as sufficient. ${ }^{8}$ The formalistic nature of the seal is now completely revealed by the cases holding that a scroll,9 the word "seal,",

$x$ Turner, Remarks on Personal Seals During the Middle Ages, 5 The Archeological Journal, I (I850).

2 Blackstone's Commentaries 306 (Igth ed. I866).

3 The most important rule was that rendering sealed contracts binding without consideration. Nor was fraud in the obtaining of a sealed instrument a defense at common law. Unless it was apparent on the face of the instrument, evidence could not be introduced to show that a deed was for illegal or immoral purposes, etc. For a full discussion of these and additional rules, see Ames, Lectures on Legal History ro6-II5 (I9r3).

4 Decker, The Case of the Sealed Instrument in Illinois, I Ill. Law Bull. I38, I64 (Igr7).

$s$ Ames, op. cit., supra, note 3, II4.

${ }^{6} \mathrm{I}$ Coke, Institutes I69 (Hargrave and Butler ed. x794).

${ }_{7} 4$ Kent, Commentaries 452 (I4th ed. I830); Warren v. Lynch, 5 Johns. (N.Y.) 234 (r8ro).

${ }^{8}$ Connolly v. Goodwin, 5 Cal. 220 (1855); Nat. Bank v. Jackson, 33 Ch.D. I (I886); Hendee v. Pinkerton, 14 Allen (Mass.) 38r ( 1867 ); Pillow v. Roberts I3 How. (U.S.) 472 (I85I).

9 Eames v. Preston, 20 Ill. 389 (I858); Jones v. Logwood, $x$ Wash. (Va.) 42 (I79I).

ro Whitley v. Davis' Lessee, I Swan. (Tenn.) 333 (I85I); Jackson v. Security Mutual Ins. Co., 233 III. I6r, 84 N.E. I98 (Ig08). By statute, Rhode Island gives to the word "covenant" the same effect as a seal. R.I. Gen. L. $1923,4270$. 
the letters "L.S.,", satisfy the requirements for a seal.

The decisions in Illinois illustrate sharply the conflict springing from the operation of these modern tendencies upon the efforts of the courts to maintain the common law position. With regard to the formal requirements, an early Tllinois statute ${ }^{\mathrm{x}}$ rendered a scroll sufficient as a seal. A comparatively recent case, ${ }^{\mathrm{I}}$ on the other hand, refused to uphold as sealed an instrument with a scroll made in Oregon, in the absence of proof of a statute rendering a scroll sufficient in that state. The court held that a scroll was insufficient at common law. ${ }^{\mathrm{Is}}$ While the usual rule in Illinois is that a seal "imports" consideration, ${ }^{16}$ by which it is meant that a seal provides irrebuttable evidence of consideration, it has been suggested that it is but presumptive evidence. ${ }^{17}$ Furthermore, it is well established that, despite the seal, want of consideration may be set up as a defense to contracts of guaranty..$^{18}$ However, so secure is the position of the seal in releases, that it cannot be impeached for fraud except in equity. ${ }^{19}$ On the other hand, although in some states options under seal have been held to constitute an exception to the rule that equity will inquire into and require valuable consideration, ${ }^{20}$ this exception has not been made in Illinois. ${ }^{2 x}$

Apparently feeling that these tendencies must ultimately lead to the abandonment of the seal, ${ }^{22}$ and dissatisfied with the confused state of the law, the

II Ankeny v. McMahon, 4 Ill. I2 (I84I); Hastings v. Vaughn, 5 Cal. 3 I5 (I855).

${ }^{12}$ Hacker's Appeal, I2I Pa. I92, I5 Atl. 500 (I888). The rule that the presence of the word "seal" is sufficient to satisfy the requirement for a seal seems analogous to the rule, in a minority of jurisdictions, that a recital of consideration estops the signer from denying the consideration. Schneider v. Turner, I30 Ill. 28, 22 N.E. 497 (1889). See Lawrence v. McCalmot, 2 How. (U.S.) 426, $45^{2}$ (1844); Redfield v. Haight, 27 Conn. 31, 40 (I858); Erzinger v. Gerrity, $27 \mathrm{I}$ Ill. App. $450,45^{8}$ (1933); Drury v. Fay, 14 Pick. (Mass.) 326 (1833). This view has been criticized. I Williston, Contracts $\S$ II 5 b (Ist ed. I920).

23 Ill. Rev. L. (1826-27) 320; Ill. Rev. Stat. 1935, c. 29, \& I.

${ }^{14}$ Woodbury v. U.S. Casualty Co., 284 Ill. 227, I20 N.E. 8 (IgI8).

is $C f$. cases in note 9 sulpra.

${ }^{16}$ Forthman v. Deters, 206 Ill. I59, 69 N.E. 97 (I903); Adams v. Peabody Coal Co., $230 \mathrm{Ill}$. 469, 82 N.E. 645 (I907); Chamberlin v. Sanders, 268 Ill. 4r, ro8 N.E. 666 (19I5).

${ }^{17}$ See Ruppert v. Frauenknecht, r46 Ill. App. 397 (rgo9).

${ }_{18}$ Bullen v. Morrison, 98 Ill. App. 669 (I9or); Bartholomae v. Motycka, I6 3 Ill. App. 238 (Igrr); Woodbury v. Ocean Acc. \& Guaranty Corp., 205 Ill. App. 387 (r9I7).

I9 Jackson v. Ins. Co. 233 Ill. I6I, 84 N.E. I98 (I908); See Woodbury v. Casualty Co., op. cit. supra note I4.

${ }^{30}$ I Ames, Cases on Equity 433 (Igor); Clark, Equity I70 (IgIg); O'Brien v. Boland, I66 Mass. $48 \mathrm{I}, 44$ N.E. 602 (I896); Mansfield v. Hodgden, I47 Mass. 304, I7 N.E. 544 (I888); Borel v. Mead, 3 N.M. 39 (I884); 2 Chafee and Simpson, Cases on Equity II59 ff. (I934).

${ }^{2 x}$ Corbett v. Cronkhite, 239 Ill. 9,87 N.E. 874 (Igog) which illustrates a commercial situation in which it seems desirable that the promise be enforcible without consideration.

22 In this discussion certain broad exclusions have been made in order to confine the discussion to the position of the sealed contract at law. The corporate seal, having an entirely different background and use from the private seal, is not considered. The Uniform Negotiable Instruments Law, adopted by virtually every jurisdiction, treats the presence of a seal on nego- 
Illinois legislature passed a statute in 1874 which was designed to limit seriously the effect of the seal..$^{23}$ Despite the broad language of the statute, which might have been interpreted as extending to all instruments, ${ }^{24}$ the statute has been limited in its application to negotiable instruments. ${ }^{25}$ In other states, the efforts of the legislatures have been more fruitful. In twenty-four jurisdictions ${ }^{26}$ statutes have been passed abolishing altogether the distinction between sealed and unsealed instruments; in seven states, ${ }^{27}$ acts have reduced the effect of the seal so that it merely raises a presumption of consideration. Except in those jurisdictions ${ }^{28}$ where the latter statutes have been taken to raise conclusive rather than rebuttable presumptions of consideration, the presence of the seal has little substantive value. ${ }^{29}$ Of the states abolishing the seal by statute, three ${ }^{30}$ give to unsealed written promises the effect which sealed contracts had at common law. Thirteen other states ${ }^{3 \mathrm{x}}$ provide that any written contract shall be presumed to

tiable instruments as superfluous and ineffective, so that only non-negotiable instruments are considered here. Equity will usually inquire into consideration regardless of the seal, and we are chiefly concerned with the legal position of the seal. And finally, it does not seem desirable to go into the various rules of pleading and evidence which the seal involves, for these rules bear little or no relation to the value or desirability of the seal.

${ }^{23}$ Cahill's IIl. Rev. Stat. (I935) c. 98, $\S$ ro (original statute in 1874 ) reads: "In any action upon a note, bond, bill or other instrument in writing for the payment of money or property, or the performance of covenants or conditions, if such instrument was made or entered into without a good and valuable consideration or if the consideration . . . has failed, it shall be lawful to plead such want of consideration or that the consideration has .... failed; and if it shall appear that such instrument was made or entered into without a good or valuable consideration or that the consideration has wholly failed, the verdict shall be for the defendant."

24 Decker, The Case of the Sealed Instrument in Illinois, x Ill. Law Bull. 65,83 ff. (rgr 7 ).

${ }_{25}$ The Chicago Sash, Door and Blind Mfg. Co. v. Haven, 195 Ill. 474, 63 N.E. 158 (Ig02).

${ }^{26}$ Comp. L. Alaska I9I3, c. I00, $\S$ I873; Rev. Code Ariz. I928, c. 73, § 3048; Ark. Const. of I874 schedule § I; Cal. Civ. Code I93I, § I629; Idaho Ann. Code I932, T. 28, § ro8; 2 Burns Ann. Ind. Stat. x933, T. 2, § 160x; Code of Ia. x931, c. 420, § 9439; Kas. Rev. Stat. r923, c. I6, § 106; Carroll's Ky. Stat. 1930, § 47x; 2 Mason's Minn. Stat. 1927, c. 45, § 6933; I Miss. Code Ann. I930, c. 62, § 3302; Rev. Stat. Mo. I929, § 2957; Mont. Rev. Codes I92I, c. II, $\S 7524$; Comp. Stat. Neb. 1929, c. 76, § 256; Nev. Comp. L. I913, c. 55, §5894; New Mexico Ann. Stat. I9I5, § 218I; Comp. Laws N.D. I9r3, c. 55, \$ 5894; Throckmorton's Ann. Code Ohio I934, § 32; Okla. Stat. I93r, c. 44, §9458; Comp. L. S.D. I929, § 864; Michie's Tenn. Code Ann. I932, c. I3, § 7828; I Vernon's Ann. Tex. Stat. 1925, art. 27; Remington's Rev. Stat. Wash. 1933, T. 73, § 10556; Wyo. Rev. Stat. x93I, c. 97, § x22.

${ }_{27} \mathrm{Ala}$. Code I928, c. 330, $\S 946 \mathrm{I} ; \mathrm{Ga}$. Code 1933 , c. 20, §30I; Comp. L. Mich. I929, c. $266, \S$ I4200; N.J. Comp. Stat. I9Ix, p. 2240, § 66; Cahill's N.Y. Civil Practice I93I, § 342; Ore. Code Ann. 1930, T. 9, c. 7, § 704; Wis. Stat. Ann. r933, $\S 328.27$.

${ }^{28}$ Aller v. Aller, 40 N.J. 446 (1878).

29 Township of Danby v. Beebe, 147 Mich. 312, 110 N.W. ro66 (1907).

${ }^{30}$ I Miss. Code Ann. I930, § 3303; N.M. Ann. Stat. I9I 5, § 218r; Wyo. Rev. Stat. 193r, c. $97, \S I 23$.

${ }^{3 x}$ Rev. Code Ariz. I928, c. 73, $\$ 3048$; Cal. Code Civ. Prac. I929, \$\$ I932, I963; Ann. Code Idaho 1932, T. 28, § 103; Code of Iowa I931, c. 240, § 9440; Kas. Rev. Stat. 1923, c. 16, § 107; Carroll's Ky. Stat. I930, $\S \$ 470,47 x$; Rev. Stat. Mo. I929, § 2958; 2 Choate's Rev. Codes Mont. I92I, c. Io, $\$ 75$ I2; Comp. L. N.D. I9I3, c. 55, § 588I; Okla. Stats. I93I, § 9449; 
be for sufficient consideration, but all the cases found treat the presumption as rebuttable..$^{2}$ Even if such statutes were construed as providing for a conclusive presumption, it is doubtful whether they would create a satisfactory substitute for the seal. ${ }^{33}$

It is no wonder, in the face of all this confusion, that there are demands ${ }^{34}$ for the complete abolition of the seal and that half the states ${ }^{35}$ have passed abolishing statutes. Even were the law of seals uniform and unequivocal there would still be many valid arguments against its continued use. Why should the word "seal," or a scroll on a printed form have the magic effect of giving the paper a dignity it would not possess were the formality of the seal not present? The layman cannot be expected to realize the consequences of affixing a seal; how, then, can one find an intention on his part to place himself under an obligation more binding and unimpeachable than a simple contract? Not only is the seal an anachronism, but it seems no longer desirable that it accomplish most of its old common law functions. It seems that fraud should be an available defense in any contract action; that if there is a variation in length of periods of limitation of actions, the variation should be based upon some more fundamental consideration than the presence or absence of a seal..$^{6}$ But the strongest argument against the continued use of the seal is the confusion and inconsistency in the present law. ${ }^{37}$ The tendency away from the seal has led to distrust and confusion on the part of lawyers and laymen in the states where it is still in use, and in the others, the result of an effort to avoid this confusion has been either too general an application of the test of consideration, or the danger of confusion arising from an unsatisfactory substitute for the seal. ${ }^{8}$ Perhaps there is a danger that the movement for uniform laws may be carried too far, ${ }^{39}$ but the unsatisfactory state of the law on this point seems to furnish strong arguments for a uniform standard. These arguments, appealing as they may be to one interested

Comp. Laws S.D. I929, $\S 848$; Michie's Tenn. Code Ann. x932, c. I3, § 7829; I Vernon’s Ann. Tex. Stat. r925, art. 21 .

${ }^{23}$ E.g. Porter v. Title Guaranty Co., 17 Idaho 364 , ro6 Pac. 299 (I909); Bank v. Hunter, 216 Mo. App. 334, 264 S.W. 54 (I924); Combs v. Combs, I30 Ky. 827, II4 S.W. 334 (1908).

33 I Williston, Contracts $\S 219$ (Ist ed. I924). 9 N. Car. L. Rev. 196 (193I).

${ }^{34}$ See Decker, op. cii. supra note 4; Crane, The Magic of the Private Seal, ${ }_{5}$ Col. L. Rev. 24 (IgI5); Maus v. Worthing, 4 Ill. 26 (I84I); Goldsborough v. Gable, 36 Ill. App. 363 (I889).

35 See note 26 supra.

${ }^{36}$ Many states have periods of limitation for actions upon sealed instruments different from the period applicable to simple contracts. Persons v. Dallas, $x 78 \mathrm{Ga} .778, \times 74$ S.E. 699 (x934); Maynicke v. Maynicke, 274 N.Y.S. 864 (1934); Parsons Trading Co. v. Dohan, 312 Pa. 464, I67 Atl. 3 Io (1933). See Crane, op. cit. supra, note 34 .

37 See pp. 314-15 supra.

${ }^{8}$ The statutes to the effect that consideration is presumed in all written contracts (see note 3 supra) or that all writings are to be treated as though they were sealed (supra, note 30 ), appear to be designed as substitutes for the seal. Their ineffectiveness has been discussed (note 33 supra).

39 Hemphill, The Uniform Law Craze, 5 American Mercury 59 (1925). 
in an orderly, rational system of law, present no solution of the difficulty other than the development of a rule making all promises dependent upon consideration for their legal force, $4^{40}$ or the creation of a rational substitute for the seal. In considering whether such a substitute is desirable, the Uniform Written Obligations Act ${ }^{4 \mathrm{I}}$ may be used as an example. This act reads:

A written release or promise hereafter made and signed by one of the persons releasing or promising shall not be invalid or unenforceable for lack of consideration, if the writing also contains an additional express statement, in any form of language, that the signer intends to be legally bound.

Such an act seems to be the logical outcome of the tendency to liberalize the requirements for a formality to render a promise binding. In the transition from the form originally required for the seal to that which suffices today ${ }^{42}$ increasing emphasis has been placed upon the maker's intention; in the act the only requirement is a written expression of such an intention. The act also calls a timely halt to the tendency toward the application of the same criteria of enforceability to all promises. ${ }^{43}$

The objection most frequently raised to the Uniform Written Obligations Act is its apparent opposition to the doctrine of consideration. Prof. Steele ${ }^{44}$ has argued ably against this act, but his entire argument seems to rest upon the view that the doctrine of consideration ought to be universally applied. In this view he is opposed by a considerable body of opinion. ${ }^{45}$ Moreover his opinion seems inconsistent with the requirements of practical justice. The various devices by which charitable subscriptions are enforced, ${ }^{4}$ the general deference accorded releases, ${ }^{47}$ the attempts to establish a doctrine of promissory estoppel, ${ }^{48}$ and, indeed, the law of most of our states which either through the seal or statutes makes possible the enforcement of some promises not backed by consideration, all evidence a desire not to subject all promises to the standards of consideration.

Nor is it to be supposed that the proposed act would to any great degree limit the application of the test of consideration. The act, after all, is hardly more than a substitute for the common law seal, and it is observable that even in those

${ }^{40}$ Steele, The Uniform Written Obligations Act, 2I Ill. L. Rev. I85 (I926).

4I This act was framed by Professor Williston and recommended by the Commissioners on Uniform Laws in r925. 9 Uniform Laws Annotated 43I (1932), I934 Supp. I35. For discussion of this law by eminent authorities see Handbook of the National Conference of Com-

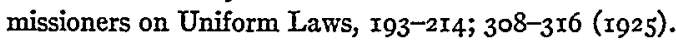

4 See notes 6-I2, supra. $\quad{ }^{43}$ See p. 312 supra. $\quad{ }_{44}^{4}$ Steele, op. cit. supra note 40.

45 See Williston's arguments before the Conference of Commissioners on Uniform Laws (note 4I, supra) and his letter to Prof. Decker printed in I Ill. I. Bull. I67 (I9I7). Also Ashley, Doctrine of Consideration, 26 Harv. L. Rev. 429 (r913); Lorenzen, Causa and Consideration in Contracts, 28 Yale L. J. $62 x$ (Igrg); Cf. Wigmore, Scientific Rôle of Consideration in Contract, Essays in Tribute to Orrin Kipp McMurray 64I (I935).

${ }^{46}$ Carver, Consideration in Charitable Subscriptions, I3 Cornell L. Q. 270 (I928); Billig, Consideration in Charitable Subscriptions, I2 Cornell L. Q. 467 (1927).

${ }^{47}$ Some of the Commissioners opposing the Uniform Written Obligations Act favored such an act for releases only. See Handbook, op. cit. supra note $4 \mathrm{I}$.

$4^{8}$ Rest., Contracts, § 90 (I932). 
jurisdictions where the seal retains its common law effect, the vast majority of contracts are based not upon the seal, but upon consideration. ${ }^{49}$ And as Professor Williston repeatedly pointed out in the conference of commissioners, ${ }^{50}$ this law would have no effect whatsoever on the doctrine of failure of consideration. If the parties bargained for consideration and also stated an intention to be legally bound, neither has expressed an intention to be bound for nothing, and failure of the consideration would render the contract unenforceable.

It is truthfully saidsr that this act presents certain difficulties of interpretation. Just what will fulfill the requirement of an "additional express statement .... that the signer intends to be legally bound"? Will an express statement from which it can be inferred that the signer believes himself bound be enough? Or must he say so in so many words? What does the word "additional" require? But these questions should, in a short time after the adoption of such a law, be answered by judicial interpretation.

Another cogent argument against the act is that the presence of such a statement on a printed form might cause unwitting signers to render themselves liable contrary to their intention. The answer to this is that it is probably impossible to conceive of a state of the law on this question wherein individuals can be fully protected from the results of their inadvertent acts. The "scroll" as a seal presents an even greater danger of innocent mistake. It seems desirable that a man be able to make a binding voluntary promise if he chooses, and as yet, no means has been put forward which will give him an opportunity to do so without subjecting him to the possibility of becoming bound, through his own error, by a promise he did not intend to keep. This statute, better than any as yet suggested will minimize the danger of injustice to those acting in good faith.

Although this law was approved by commissioners from about two-thirds of the states represented at the national conference, and although many of the uniform laws ${ }^{52}$ recommended by that conference have been widely adopted, in the ten years since the recommendation of this law, only two states, Pennsylvania ${ }^{53}$ and Utah, ${ }^{54}$ have adopted it. It is also disconcerting to note that neither state has abolished the seal, and that this statute appears to have had no effect whatsoever in promoting the abandonment of the seal.55 Furthermore, the paucity of litigation involving the question has left the meaning of the words "additional express statement" as unsettled as it was on the day the law was passed. The only case ${ }^{6}$ the writer has been able to find involving an interpretation of these

49 Williston in Handbook, op. cit. supra note $4 \mathrm{I}$, at $2 \mathrm{I} 2$. so Ibid.

${ }^{5 x}$ Reeve, The Uniform Written Obligations Act, 76 U. Pa. L. Rev. 580 (Ig28); Steele, op. cit. supra note 40 .

${ }^{2}$ E.g. Uniform Negotiable Instruments Law, Uniform Sales Act, etc.

${ }^{53} 33$ Purdon's Pa. Stat. § 6 (I930); Public Laws 958, no. 475 (r927).

54 Utah L., c. 62 (I929).

ss Balliet v. Fetter, 314 Pa. 284, r7x Atl. 466 (1934); In re Burns' Contested Election, 315 Pa. 23, x71 Atl. 888 (1934).

s6 Gilmore, Executrix v. Kessler, 22 Dist. \& County of $\mathrm{Pa}$, 274(I935), see 3 Univ. Chi. L. Rev. 336 (1936). Cf. Real Estate Co. of Pittsburgh v. Rudolph, 30I Pa. 502, I53 Atl. 438 (I930) 
words was a lower court case in which the note upon which the plaintiff was suing contained two promises to pay. This was held to bring the note within the Uniform Written Obligations Act. Such a result, while it may not be undesirable in this case, does reveal the possibility of overly loose interpretation of the meaning of the act. For if two promises to do the same thing constitute an expression of an intention to be bound, why does not a single promise serve the same purpose? The result of further interpretation of this sort might well be to make all written promises binding.

\section{ESTOPPEL OF THE CONDITIONAL SELLER IN LLINOIS, FOR DELAY AFTER DEFAULT BY THE BUYER}

After Sherer-Gillette Co. v. Long, , which held that the buyer's possession under a conditional sale contràct was not ground for estopping the seller as against third persons claiming through the buyer, the validity of the seller's reserved title in Illinois was regarded as unquestionable. The decision abruptly reversed the former practice of protecting transferees and creditors of the buyer, and gave apparently unrestricted protection to the seller.2

Three decisions of the Illinois Appellate Courts since the Sherer-Gillette case, however, have imposed restrictions upon the seller's reserved title. In each case the seller had delayed "unreasonably" in asserting his rights after a default by the buyer on the last ${ }^{3}$ installment. In one case the seller was estopped by a lien creditor of the buyer who attached after the default.4 In two cases the estoppel protected bona fide purchasers who bought the property after the default. ${ }^{5}$ The

in which the defendant delivered to the plaintiff an unsealed instrument purporting to give the plaintiff for a consideration of one dollar, an option to purchase land. Although the dollar was never paid, it was held that the defendant was bound. In 79 U. Pa. Law Rev. II39 (193I) it is suggested that the Uniform Written Obligations Act, which was already operative in Pennsylvania, may have influenced this decision. Perhaps it also indicates that the Uniform Written Obligations Act is the logical consequence of the suggestion of Prof. Decker (I Ill. Law Bull. I 72) that the recital of a nominal consideration should take the place of the seal by an extension of Justice Story's opinion in Lawrence v. McCalmot. See supra note I2.

${ }^{2} 3$ I8 IIl. 432, 149 N.E. 225 (1925). The decision changed the existing law and was based on $\S \S 2 x$ and 23 of the Uniform Sales Act. For a criticism of Sherer-Gillette v. Long, see 20 IIl. L. Rev. 709 ( 1926 ). The Pennsylvania Supreme Court held that $\$ \$ 20$ and 23 did not affect the rights of sellers and third persons. See Anchor Concrete Co. v. Pa. Brick and Tile Co., 292 Pa. 86, 90, I40 Atl. 766, 767 (1928).

2 At common law, in Tllinois, Maryland, and Pennsylvania, the reserved title of a conditional seller was invalid as against bona fide purchasers and lien creditors of the buyer in possession. See Bogert, Commentaries on Conditional Sales, Unif. Laws Annotated, Vol. 2A, 58 (I924).

3 The seller has not been estopped for a delay in an intermediate, as distinguished from a final payment. Silverthorne v. Chapman, 259 Ill. App. 289 (1930).

4 Haines v. Doss, 269 Ill. App. 179 (1933).

5 Provus Bros. v. Sjolander, 273 IIl. App. 374 (1934); Dayton Scale Co. v. General Market House, 248 IIl. App. 279 ( $x 929$ ). By reversing on another ground, the Illinois Supreme Court impliedly recognized the validity of estoppel doctrine, 335 Ill. 342 , I67 N.E. roo (1929). 